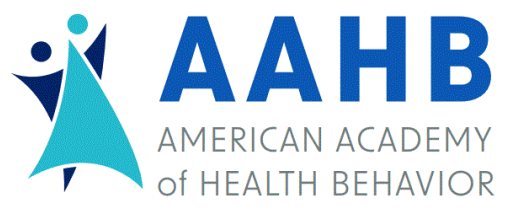

\section{Health Behavior Research}

Volume 1 | Number 1

Article 1

October 2017

Front Matter - Vol 1, Issue 1

Rita DeBate

University of South Florida, rdebate@health.usf.edu

Follow this and additional works at: https://newprairiepress.org/hbr

(c) $\underset{\mathrm{BY}}{(\mathrm{i})}$ (9)

This work is licensed under a Creative Commons Attribution-Noncommercial 4.0 License

\section{Recommended Citation}

DeBate, Rita (2017) "Front Matter - Vol 1, Issue 1," Health Behavior Research: Vol. 1: No. 1. https://doi.org/ 10.4148/2572-1836.1015

This Editorial is brought to you for free and open access by New Prairie Press. It has been accepted for inclusion in Health Behavior Research by an authorized administrator of New Prairie Press. For more information, please contact cads@k-state.edu. 


\title{
Front Matter - Vol 1, Issue 1
}

\begin{abstract}
This is the front matter of Volume 1, Issue 1 of Health Behavior Research. It includes the Table of Contents with links to the published articles and publication information.
\end{abstract}

Table of Contents

Editorial

- Note from the AAHB President

M. Renée Umstattd Meyer

- 2018 AAHB Annual Scientific Meeting - "An Equity Approach to Health Behavior Innovations"

M. Renée Umstattd Meyer

Research Articles

- The Future of Health Behavior Research: A Modified Delphi Study Jay E. Maddock, M. Renée Umstattd Meyer, Adam Barry, Brian Colwell

- Do injunctive and descriptive normative beliefs need a value-laden expectancy models? A Case Series Across Multiple Health Behaviors Paul Branscum, Maria Collado Rivera, Grace Fairchild, Katie Qualls Fay

- Relationship of Self Determination Theory Constructs and Physical Activity and Diet in a Mexican American Population in Nueces County, Texas

Joan E. Cowdery, Jiawei Xing, Brisa Sanchez, Kathleen M. Conley, Ken Resnicow, Lewis Morgenstern, Devin L. Brown

- Weight-Loss Treatment-induced Physical Activity Associated with Improved Nutrition through Changes in Social Cognitive Theory Variables in Women with Obesity James J. Annesi, Nicole Mareno

\section{Current Issues}

- The American Academy of Health Behavior 2017 Annual Scientific Meeting: "Health Behavior Research in the Age of Personalized Medicine"

AAHB Board and 2017 Conference Committee

\section{Commentaries}

- The Future of Health Behavior Research John B. Lowe

- Commentary on Future of Health Behavior Research: Aging Perspectives Marcia G. Ory

- Reflections on 15 years in the global tobacco trenches 
Kenneth D. Ward

Keywords

introductory

This editorial is available in Health Behavior Research: https://newprairiepress.org/hbr/vol1/iss1/1 


\section{AMERICAN ACADEMY OF HEALTH BEHAVIOR}

\section{PUBLICATION INFORMATION}

Health Behavior Research $(H B R)$ is the official journal of the American Academy of Health Behavior. $H B R$ is a peer-reviewed open-access scholarly journal that publishes original research articles, current issues papers, commentaries, and abstracts from the annual meeting of the Academy. The aim of the journal is to advance the science of health behavior research. $H B R$ is published four-times per year, particular emphasis is placed on papers that address concepts and theory used in health behavior research, conceptual frameworks, methods, and analyses. This journal provides immediate open access to its content on the principle that making research freely available to the public supports a greater global exchange of knowledge.

HBR does not charge submission or publication fees.

Manuscripts are accepted for consideration with the understanding that: (1) at least one author is a current member of the American Academy for Health Behavior; (2) it has been submitted solely to HBR; (3) it has not been previously published, either in whole or in part; and (4) the contents have not been posted previously in any online format.

Submission of a manuscript is understood to indicate that the authors have complied with all policies as delineated in this document and the Editorial Policies. The editors adhere to the ethical standards established by the Committee on Publication Ethics (www.publicationethics.org) who will adjudicate any breach of scientific integrity. Individuals who violate these policies are subject to editorial action including, but not limited to: (1) disclosure of violations to employers, funding agencies, or other journal offices; and/or (2) publication of a retraction, correction, editorial expression of concern, or editorial.

The editors reserve the right to make editorial changes in all matter published within the journal, although the authors' consent will be sought for any significant changes. The editors, editorial board, sponsoring organization, and publishers are not responsible for the statements expressed by authors in their contributions.

Contents of the Journal are archived for perpetual access through New Prairie Press' participation in CLOCKSS (Controlled Lots of Copies Keep Stuff Safe) and Portico and managed through the Digital Commons Publishing platform. New Prairie Press also participates in LOCKSS (Lots of Copies Keep Stuff Safe). Once published, the contents are never changed.

Permissions: Requests for copyright permissions should be directed to the Editor.

For more information, please contact Iverta Allen at $\underline{\text { HBR@usf.edu }}$ 